\title{
Exploring the Role of Computers in Knowledge Construction of Young Learners in a Constructionist Classroom
}

\author{
Archana Joshi \\ School of Liberal Arts, King Mongkut University of Technology Thonburi, Bangkok, Thailand \\ Pornapit Darasawang \\ School of Liberal Arts, King Mongkut University of Technology Thonburi, Bangkok, Thailand \\ Saowaluck Tepsuriwong \\ School of Liberal Arts, King Mongkut University of Technology Thonburi, Bangkok, Thailand
}

\begin{abstract}
This is an exploratory study which investigates a young learner constructionist classroom's knowledge constructions by using computers. It is part of an on-going research which had ten participants ranging between 6-7 years of age. However, in this study only three participants out of the ten have been covered. The study was conducted in a project-based classroom where the participants had to build artefacts for knowledge construction. Data was collected through field observations, semi-structured interviews, learner journals and learner logs. The evidence of knowledge construction was found in the artefacts made by the participants. The results show that using computers to mediate the participants' learning at different stages facilitated meaningful interactions between participants and peers and participants and facilitators, encouraged autonomy and provided itself as a source of information for exploration of ideas, which had a positive impact on participants' knowledge construction.
\end{abstract}

Index Terms - knowledge construction, constructionism, project-based, young learners, mediation tool, computers, artefact building, peer/facilitator interaction, autonomy

\section{INTRODUCTION}

The computer is a powerful tool, which has the potential to not only support learners in their process of knowledge construction but also to improve their social interactions and create a positive environment in the classrooms (Clements \& Sarama, 2003; McCarrick \& Li, 2007 cited in Spink et al., 2010; Klinzing, 1985).

Studies show that children engage with computers with confidence and ease and enjoy working on them (Binder \& Ledger, 1985 cited in Clements \& Nastasi, 1992). According to Papert (1998 cited in Haugland, 2000, p.2) “...computers have an impact on children when the computer provides concrete experiences, children have free access and control the learning experience, children and teachers learn together, teachers encourage peer tutoring, and teachers use computers to teach powerful ideas." Turkle and Papert (1990) suggested the importance of computers as more of a concrete physical artefact which did more than computation but provided "a context for the development of concrete thinking" (p.346).

Constructionism, a cognitive learning theory, explains how knowledge is constructed in the minds of individuals, and how students apply their previous knowledge to further build or reconstruct new knowledge (Sripongwiwat, et al., 2016). In this learning method, learners construct their knowledge by making meaningful artefacts which are shareable (Papert and Harel, 1991) and in the process they use past and present experiences to reconstruct new knowledge. Technology is seen as a tool which can facilitate the process of artefact building, allowing individuals to develop their ideas and express themselves in a more independent way, thus developing learner-centeredness.

This study was conducted in a young learner constructionist classroom and is a part of an on-going research. The focus of this paper is on the use of computers in a young learners' constructionist classroom environment, and how they construct knowledge through computers; this research addresses the question:

How did the use of computers facilitate knowledge construction in young learners at different stages of learning in a constructionist learning environment?

\section{LITERATURE REVIEW}

Constructionism is not only a theory of education developed by Seymour Papert (Falbel, 1993), but also pedagogy of learning (Papert, 1980, 1987 cited in Griffin, 2018). It is constructivist in nature and has a mix of concepts from Jean Piaget's constructivism and Vygotsky's socio cultural theory (Fostnot, 2005; Ackermann, 2001). For Piaget, children 
are more like explorers, who explore the world around them and use their experiences to construct their understandings (Edwards, 2005; Palmer, 2005; Windschitl, 2002 cited in Mills, 2007). In Vygotsky's socio-cultural theory children acquire knowledge from culture through interactions with people in their environment such as adults or their more capable peers (Vygotsky, 1978). Papert integrates both individual and social aspects and includes the affective component in the process of learning (Papert, 1980). He showed the importance of the affective component by giving an example of how his playing with gear mechanisms in his childhood influenced his interest in equations and further explained how through LOGO learners were encouraged to explore geometry as they enjoyed working on it (Papert, 1980). Papert (1987) also explains that constructionism is about reconstruction and not transmission of knowledge and "learning is the most effective when part of an activity the learner experiences as constructing a meaningful product" (p.1). In constructionism individuals are builders of their own knowledge (Papert, 1980) and constructionism focuses on 'learning to learn' (Ackermann, 2001).

Computers provide a broad range of contexts for learning (Papert \& Harel, 1991). Studies done earlier have shown the benefits of computer use by children such as in their literacy, social, cognitive and language development skills (Clements and Sarama, 2003; McCarrick and Li, 2007 cited in Spink et al., 2010). In their research, Spink et al. (2010) found that the use of computers could create collaborative behaviours in learners. Help from peers was also found useful while querying information on the Internet. The study also showed that children who are 4-5 years old use the Internet for both -web queries and browsing (Spink et al., 2010). Various studies (Hoven, 2006; Winke \& Goertler, 2008; O’Bryan, 2008 cited in Hayta \& Yaprak, 2013) show that if learners are trained in using technology, they benefited the most from their learning.

For the above reason computers occupy an important place in constructionism (Papert and Harel, 1991). For example, MIT Media Lab created a visual programming system called 'Scratch' that helped learners to engage in concrete experiences. Through using this computer program learners could create, develop and share their stories or thoughts with others or even make animations, game, art, music, etc. (Lamb \& Johnson, 2011; Beynon, 2017).

Papert (1996) also mentions the significant role of the Internet as an empowering force. He refers to its dominant spirit which allows access of the same resources to everyone. Papert and Caperton (1999) describe the holistic and transformative characteristic of computers in knowledge production and distribution through learning stories in which learners explored and sought for information on the Internet based on their personal needs and interest.

The use of a computer in the constructionist learning environment has been explained as a tool which provides people with a wide range of opportunities to try out new ideas including those ideas or things which individuals may have never tried out before or done rarely and to improvise on things that had been done before (Falbel, 1990 cited in Harel \& Papert, 1990). Implementing constructionism at the school level therefore could help learners to construct knowledge with enthusiasm and interest. In order to implement constructionism in classrooms, the project-based approach can be used. Both the approaches of learning have commonalities in them such as they are both learnercentred, emphasize learner autonomy and engage learners in real-world tasks that are personally meaningful to them (Han \& K. Bhattacharya, 2001).

Lee (2015) conducted a case study on young children's learning processes by exploring their working with iPads to make their learning meaningful. The participants were two preschool children ages3-5. The participants used an iPad with an app dealing with math, social studies, and science. They used the iPad for 45 minutes, twice per week, for one semester. Finally, at the end of the semester, there was a post assessment done. It was found that introduction with iPads helped in improving participants' interactions with their peers and teachers. They engaged in discussions with their teachers and peers during their task on the iPad and even worked together to solve problems. Their motivation increased as they engaged with the digital media and had fun.

Another study, was conducted by Cavallo, Papert and Stager using constructionism as a basis to create a learning environment for a juvenile detention facility in Maine (Stager, 2005). The objective was to engage severely at-risk students in this facility in long-term projects that were based on their personal interest, expertise and experience. These students prepared personally meaningful artefacts, using computers and other tools made available to them. It was found that the learners were completely engrossed in their work of creating new artefacts, interacting with each other about their products, and the process of making them. They showed positive student behaviour and curiosity.

\section{CONTEXT OF THIS STUDY}

\section{A. Learner Levels}

The school within the purview of this study is a school with a project-based learning approach that follows constructionism as its learning pedagogy. It had mixed age classes. The learners were of three levels- New Learners (610 years), Intermediate Learners (11 - 14 years) and Pre Advanced Learners (14-18 years). Their levels were determined based on learners' abilities and age. For example, for the age range of 6-7 years, New Learners' level , the criteria was the ability to work, understand, and conduct basic communication with peers and facilitators in Thai/English.

\section{B. Division of School Time}


The school time table was divided into- Project time (50\%), LG (Learning Guide) Time:-Thai, Math and English (30\%) and other subjects-Art, Sports, Club and Reading Time (20\%). Below is a summary of the division of school time:

\section{Division of school}

\section{time}

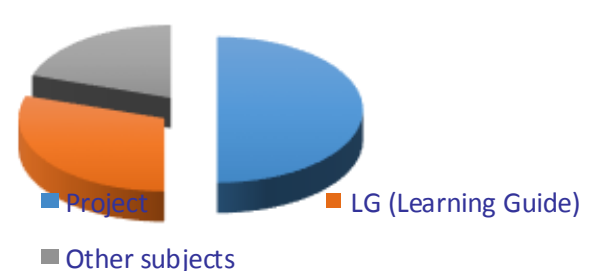

Figure 1: Division of School Time

\section{Role of Project Facilitators}

Project classes were comprised of at least one Thai and one foreign native English speaking facilitator. Both the facilitators had to facilitate learning activities in the classroom, prepare learner observation reports (biweekly), follow up on learner journals, provide feedback to learners, design and conduct classroom activities and games and conduct reflections on the learners' work. The main job of both the facilitators was to ensure learner engagement and provide learners access to all the learning resources. The foreign facilitator did various hands-on activities with the main aim of motivating learners to speak and use English; this was the main job of a foreign facilitator.

\section{Project Phases}

The phases in which this project was conducted included project selection, planning, learning, preparing for the exhibition, exhibition and post-exhibition. The figure shown below provides a summary of the project phases:

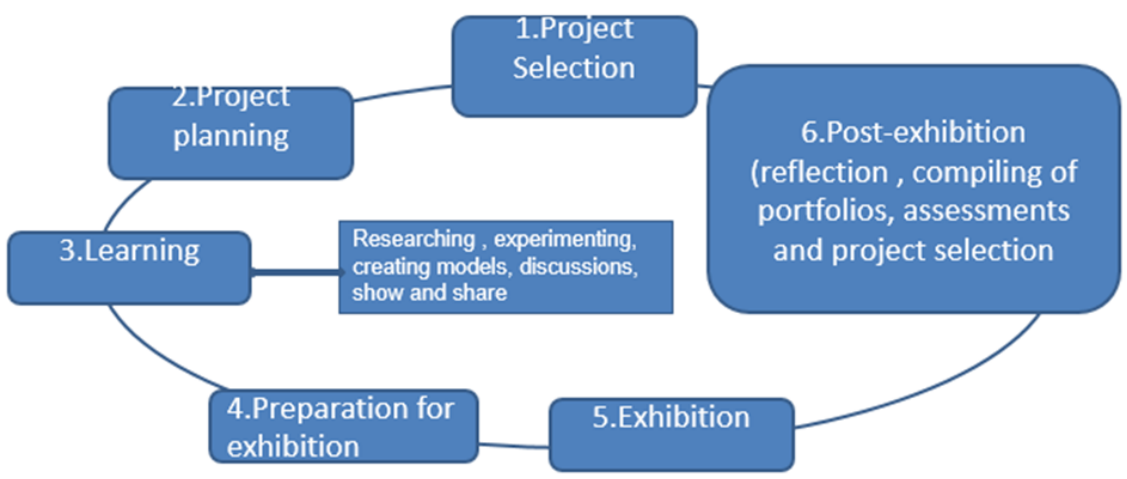

Figure 2: Summary of Project Phases

\section{Project Selection:}

The process of learning began with learners presenting and selecting their learning topics. The aim of this learning stage was to get learners to explore and present their learning topics to other learners of the same classroom. They negotiated with others and explained to others why their topics were interesting so that they could get their topics included as the main learning theme.

The learners of this study created their mind maps for their topics with the help of facilitators and using computers installed. The learners used the computers in the classroom to find more information about their topics of interest. They had also received ideas from their parents before they made their own mind maps in the class. After the mind maps had been created they presented their topics to the class. After the presentations, the learners voted for the three most interesting learning topics out of the ten choices they had by raising their hands. In this study, the three topics that the learners chose were -Beetles, Oceanography and Bananas. The project, therefore, was named BOB.

2. Project Planning:

After project selection, the next step was to discuss with the learners their learning plan such as the topics which they would like to cover first, second and third and also plan out the places for their field trip. The objective of this stagewas to plan the project's learning sequence according to learner choice to generate greater learners' involvement. In this 
stage, the learners raised their hands and expressed what they wanted to learn while the facilitators questioned them and created a large plan on the whiteboard. An example of a learning plan copied by a learner from the board is as below:

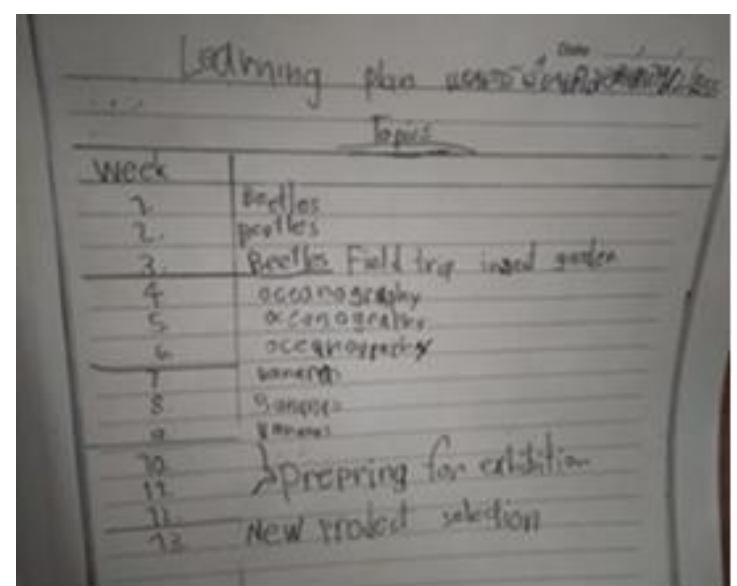

Figure 3: Example of a learning plan

\section{Learning:}

In this stage learners began to learn and create their learning models (any public entity like a story, presentation, a model, mind map, etc.) which was aligned to the topic chosen for that week by them. The learners learned through various activities designed by the facilitators but choices were given to the learners to select for themselves. These activities involved searching for information, constructing artefacts, going on field trips, collaborating, communicating, sharing and reflecting. The aim of this learning phase was to explore and to learn about the project learning themes.

4. Preparation for exhibition:

Learners prepared for the exhibition in the last two weeks before the exhibition. The aim of this learning stage was to plan for the exhibition such as- decide the products that the learners wanted to exhibit which showed what they had learnt -their knowledge constructions, games or shows that they wanted to show, etc.

\section{Exhibition:}

On exhibition day, learners presented their artefacts (which could be games, models or presentations on future board) in groups or individually to their parents, peers and facilitators, which were set up in different areas of the classroom. The aim of exhibition was for learners to present their learnings and share it with others. At the end of the exhibition, parents and facilitators had a reflection session, a small group meeting in which they all talked about the project execution and learners' progress.

6. Post Exhibition:

Learners along with the facilitators reflected on and assessed the whole exhibition planning and execution phase to judge whether it had been successful. They also created their portfolios and put all of the material received from their project and other classes into it. The aim of this learning stage was to reflect upon learners' learnings throughout the term, if they had been successful in showing and sharing their learnings during the exhibition and what could they do to further improve their knowledge constructions and presentations.

\section{E. Project Classroom Physical Environment}

In the project classroom of this study, there were 10 computers installed inside the classroom for the learners to use individually. The environment in the classroom was mostly informal, and learners sat around a large, movable table next to each other and with their facilitators. The learners were free to move around in the classroom as they did their assigned work. There was a large whiteboard in which facilitators had a corner for writing down the agenda or the day's plan and used it during facilitation. One whole wall on the opposite side of the whiteboard had a dream garden made out of paper and learners kept adding beetles, butterflies, grass, etc. on the wall as shown below.

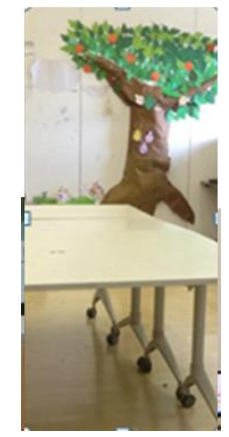

Figure 4: Picture of the dream garden 


\section{F. Participants}

There were 3 participants involved in this study- 2 boys (Bruce and Pan) and 1 girl (Jenny). Bruce, a 6-year-old boy, could speak and understand English, although not fluently. He needed help to read and write in English/Thai and while browsing on the Internet. Pan, who was a 6 year old boy, could speak and understand English to the extent that he could talk about how he was feeling, what he wanted and what he liked or disliked. He could read and write some basic words and sentences, but needed help to spell words. He could browse on the Internet with some help. Jenny was a 7-year- old girl, who was rarely heard speaking in English. She could read and write with help. She was good in reading and writing in Thai and could also browse independently on the Internet.

\section{METHODOLOGY}

\section{A. Data Collection}

Data collection was mainly through field observations. The other instruments used for data collection were semistructured interviews, learner journals and logs. The researcher was given consent from the project facilitators and learners' parents for the study. The study was conducted over 12 weeks from 17 September 2012 to 4 December 2012.

The unstructured non-participatory observations were done in project time in order to examine the classroom activities and learner interactions with their peers and facilitators. These observations helped to explore how learners constructed their knowledge.

Semi-structured interviews were done four times during the term after each theme was completed and before the exhibition with the learners. This provided the learners' perspective about their feelings, emotions and attitudes. A translator's help was used to conduct these interviews to make the communication in Thai and English more fluid as the interviews were conducted in Thai.

Journal writing had been a part of the project and learners had to write in their journals daily; therefore, the researcher used it to explore learners' feelings primarily from their perspective. The journals were unstructured and were written every day in Thai/English.

Learner logs designed by the researchers provided information about learners' feelings, interactions and knowledge constructions in the project class from the learners' point of view.

\section{B. Data Analysis}

The data was analysed by examining the stages in which the data showed learners' knowledge constructions using computers such as the Project selection phase, Learning phase and Preparation for exhibition phase. In this study, the phase of post exhibition has not been covered as the researcher observed learners till the exhibition phase.

The knowledge construction was identified by looking into the artefacts created by the learners and the process of creating the artefacts involved their computer use.

\section{ANALYSIS AND FINDINGS}

The data below shows and explains the knowledge constructions of learners in the learning phases mentioned above to explore how learners at different stages of learning constructed knowledge using computers.

\section{A. Project Selection Phase}

1. Pan's Knowledge construction: About LEGO:

The observation dated 29.8.12 shows that Pan went to Google and then screamed and called "T.X how to spell Wiki?" Then he typed it on the computer. He also asked the foreign facilitator (T.X) to explain to him what was written on it and copied it down. He wrote LEGO in his notebook. He was again observed typing and this time he wrote "Wiki" on his own (using his last notes) and then he also typed "LEGO". He then asked the Thai facilitator (T.Z) about the LEGO city (there was a picture in Wikipedia of a LEGO city), and she responded by telling him about the LEGO building at NASA. Next, Pan and T.X discussed LEGO on Wikipedia. He asked her about what was written in English and highlighted the lines on the computer and wrote it down. He also had conversations with his friends such as Greg about the LEGO city. He made a mind map about LEGO and showed his Thai facilitator that LEGO was made of plastic and that plastic is heated to 232 degrees Celsius. He finally presented his mind map in English as below:

"Hello my name is Pan.

Today I will tell you about LEGO.

I want to look at factory from LEGO. I want to learn about history and manufacturing. The plastic is heated to 232 degrees Celsius." (Observation dated 29.8.12)

His construction of understanding about LEGO happened through the use of a computer while finding information of his interest. He needed help from his facilitators to spell words in English and understand the sentences written in Wikipedia. His use of the computer generated meaningful interactions between him and others which further helped him to build his knowledge about LEGO. As he browsed and saw the picture of LEGO city on Wikipedia, it made him curious and interested. In his interview dated 29.11.12 when he was asked how he had learnt some English words he said, "By computer". In his interview dated 26.9.12, when he was asked what he did when he did not understand some 
things in English, he said (as translated by the translator):

"He found spellings of names and information using Wikipedia."

Even though his topic did not get voted to become one of the learning themes, he, however was able to build his understandings about the topic that he wanted to present to his peers and also presented it successfully.

2. Bruce's knowledge construction: About beetles:

On the same day, according to the observation of 29.8.12, Bruce looked up information about "Beetles" with the help of the Thai and foreign facilitators and discussed Beetles at length. The foreign facilitators also explained to him how beetles had become stuck in a raisin and were there for 15 million years as he kept looking at different websites containing images of beetles. The Thai facilitator showed him the beetles found in Thailand. He wrote down his mind map in English with help from the foreign facilitator.

Researcher's observations of 29.8 .12 (project selection day) show Bruce intently looking at pictures of various insects on Google Images, and the facilitators encouraged him further by helping him to explore, find and talk about the information he wanted to know. An example from the classroom observation of 29.8.12 which shows his interest in the activity is given below:

(The Thai conversations were translated from Thai to English in the classroom.)

"Bruce went to T.Z (Thai facilitator) for help. Bruce showed T.Z pictures of insects... Bruce's really impressed by beetles and keeps looking at it...Bruce was trying to finish his mind map on beetles and asked some spellings from T.X...Bruce screamed "T.X look .... insect fighting”...Bruce was sharing with T.Z some more pictures of beetles. ..Now T.Z and Bruce were looking at beetles of Thailand...T.X tells Bruce how these beetles get stuck in resin and are there for 15 million years...He read with T.X about 100 million types of beetles in the world on the Internet." (Observation dated 29.8.12)

He developed his understanding about beetles as seen from what he wrote on his mind map - "Beetles -body system, where does he come from and 100 million." He made this mind map only after he had found information about beetles on the computer with his facilitators on the project selection day. He had built his understandings about different types of beetles and wanted to know more about them.

Using computers as a learning medium gave Bruce an opportunity to explore what he liked and communicate with both of his facilitators meaningfully. He looked at beetle images intently as that was what interested him the most and helped him to further explore the topic further. Facilitators not only helped him find information but also explained what was written in English/ Thai in the websites about beetles such as reading about the number of species or types of beetles in the world and how beetles become stuck in a raisin and are there for 15 million years.

\section{B. Learning Phase}

Jenny's knowledge construction: Sea animals' food chain:

In the learning phase, Jenny developed her understandings about sea animals' eating habits with a task by making a sea food chain sheet with information about sea animals eating habits under the 'oceanography' theme.

Her positive feelings during class time was clearly evidenced in her learner log of 9.10.12 in which she circled a happy face under the project feeling of that day. She chose to write in her learner log about the work she had done on this day with her friends: "searched information" on the computer. Jenny along with her group had constructed the following understandings about sea animals (translated into English) as follows:

The starfish are the enemies of conch shells.

Sea lions eat penguins. They are lovely and smart.

The sea horses eat shells, shrimps, worms and crabs. They don't have a backbone, like a sponge.

Whales eat sea lions and small fish. Their enemies are humans and sharks. They are also an endangered species.

Penguins eat fish. Sea lions are their enemies.

Dolphins are smart.

Below can be seen a picture of the food chain sheet created by Jenny and her friends:

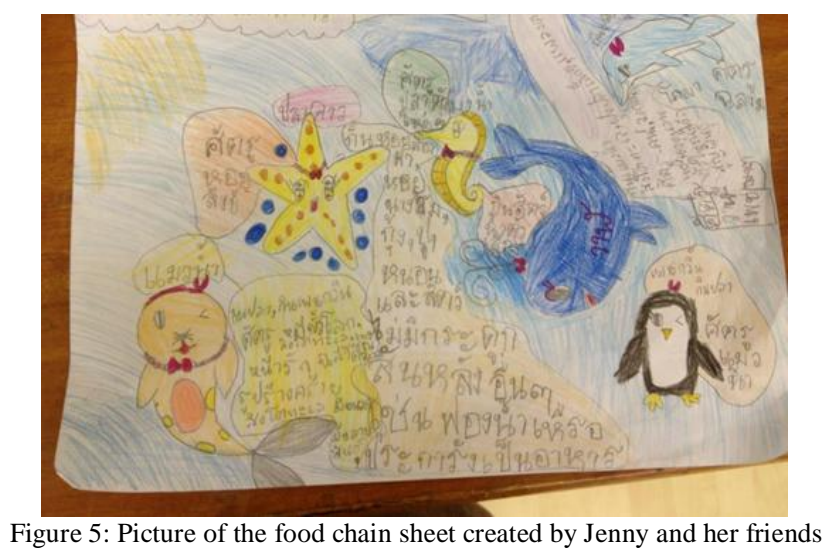


The class observation dated 9.10.12 showed that Jenny had worked in a group on this day looking for information about her favourite sea animals and their eating habits. Jenny and her team researched information on the computer in Thai. The facilitators gave them the choice to find information from computers or any other resource.

Jenny could Google in Thai on her own, which she confirmed in her interview dated 26.9.12. She found information about the starfish and gave it to Pearl, who was gathering information and also researching some information about sea lions on the computer. Fae the third team member, on the other hand, was looking for pictures of blue whales on Google. Jenny looked at the images on Google and was observed looking for information about starfish and colouring the starfish image on the paper. In a classroom discussion on the same day she had mentioned that she liked starfish because "it was like a star." She passed that information to her group member, Pearl and finally, after all the information was compiled, the sea animals' information sheet was ready.

On 11.10.12, which was after the above mentioned activity, during a food chain activity in which the learners were invited to the board to draw pictures of sea animals that were herbivores, carnivores and omnivores, Jenny and Pearl were seen drawing pictures of a starfish, a sea lion, a sea horse and a dolphin in the section under carnivorous sea animals. It was observed that Jenny and Pearl both used the food chain sheet that they had researched information to make their sea animals.

Jenny chose to prepare a fishing game for the exhibition which showed her understandings about sea animals' eating habits according to the observation dated 22.11.12. Her interview dated 29.11.12 shows that she had suggested this game for the exhibition:

Translator to Jenny: What will you present in the exhibition?

Translator to the interviewer: She will create a game about fishing. The fishing game is... when you can catch a fish you have to answer it's omnivore, carnivore and what this is prey or is predator.

Interviewer: Okay. And who gave you that idea Jenny?

(Translator asked Jenny)

Translator: She think by her own.

Computers helped her and her team members to explore information on the sea animals that they liked. The ability to access information easily on her own may have made her feel more in control of her knowledge construction. The facilitator's designed activity gave her a chance to choose what she wanted to research within the topic. Her collaborative experience while working in the group was enhanced by the intervention of computers as she had a source to not only find new information but also to show her finds to her peers.

Since Jenny was interested in the ocean theme, she also created a story about sea animals by using the 'Scratch' program which is not only an evidence of her understanding about sea animals but shows how computers promoted engagement and helped in providing her with concrete experiences. Her journal dated 3.10.12 shows that she wanted to download "Scratch" and so asked her father to help her: "I asked my father to download program "scratch" for me." She presented her created Scratch story book in the exhibition which had a story about three fish and a shark. The story translated from Thai to English was about three fish friends who never played with one of the fish in the group. One day a shark attacks the fish. All escape but one. The fish that is stuck takes refuge in a boat which is underwater and manages to save herself from the shark.

During the learning phase, Scratch was introduced in the classroom through a story of a beetle on a large screen, followed by learners who enacted the story and later created their individual stories in their drawing books. After drawing pictures on Scratch, they were helped by facilitators to learn how to use a paintbrush on 'Scratch'. They were also encouraged to explore other functions on Scratch on their own. Jenny finally presented her story on Scratch to her facilitators and peers on 22.11.12. She seems to have built an understanding that there are big sea animals in the ocean that eat smaller animals like the fish. As she worked on Scratch, she developed her creativity skills. Additionally, she was encouraged to try out new functions to program, thus promoting her self-learning.

\section{Learning Phase}

Pan's knowledge construction: About Goblin sharks:

In the preparation for exhibition phase, Pan was the only learner who was found using a computer to make his 'Goblin Shark' book for the exhibition. He constructed his understandings about 'Goblin sharks' on 26.11 .12 while preparing for the exhibition, using Wikipedia. Pan made a book as an artefact to present in the exhibition, using computers and getting help from his facilitators. He wrote the following information in English in his 'Goblin shark' book.

"The goblin shark, Mitsukurina owstoni, is a deep sea shark. It eat squid, crabs, and deep-sea fish. Gobiln Shark. It live is deep sea." 


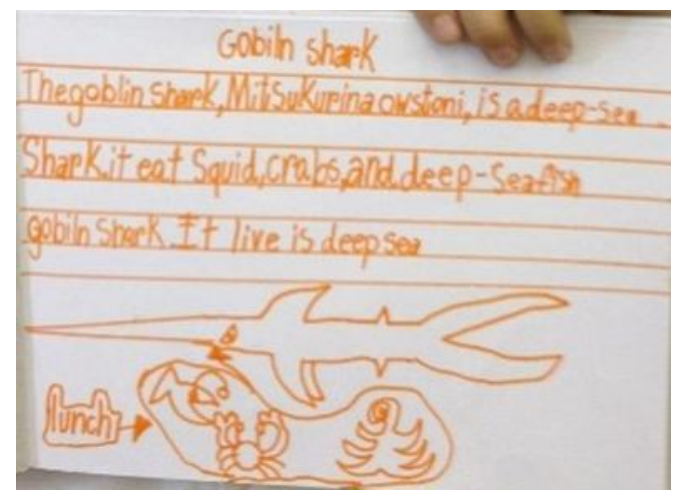

Figure 6: Pan's preparation for his 'Goblin Shark' book

Pan enjoyed making the goblin shark book for the exhibition, as he confirmed in his interview dated 29.11.12, excerpted below:

(Interview excerpt of 29.11.12)

Interviewer: So Pan, you're making a book. Do you like that? Do you want to do it?

Pan: Yes

Pan mentioned in the same interview his keenness to write in English, information about the Goblin sharks as below:

(Interview excerpt 29.11.12)

Interviewer: He has written in English right? Why not in Thai?

Translator: (Told Pan what the interviewer asked in Thai)

Pan: I know in Thai everything. Everything in Thai.

(Pan continued to speak to the translator in Thai)

Translator: He knows in the Thai language about the shark. He is very interested in the shark in English version.

He had researched information on Wikipedia and written about goblin sharks in his book, according to the observation of 26.11.12. He asked his foreign facilitator to explain the information written on Wikipedia in English; the facilitator in turn helped him by explaining some sentences and highlighting the important points for him to write. With the help of computers Pan could find information about the sea animal he liked the most-sharks. He had help from his facilitators to read and understand text in English.

The findings of this study show that in all the learning phases discussed above, computers were used as a learning mediation tool for exploration of information that the learners were interested in. In the process of exploring information on the computers, learners meaningfully interacted with their facilitators and peers to talk about their findings on the computer and if they had any problems understanding the text written in the computer.

Computers provided learners a sense of freedom to find information that they liked thereby making them feel more autonomous. This helped them to build their understandings about the topics of their interest. The findings show the potentiality of computers to be used in such a way that it allows learners to obtain formal knowledge through concrete experiences which are personal to learners and with which they can relate with. Computers allowed the learners to engage with them playfully and explore, leading to different knowledge constructions.

As learners worked on the computers they appeared to be completely engaged as they could explore different images in their areas of interest and could listen and see what their peers were doing. Computers were placed in the classroom in such a manner which allowed learners to walk freely and see what their peers did and how they worked. Learners were provided computers as a resource for learning and could be used by them as and when they needed.

It was also found that having basic skills of reading and writing in English/Thai and basic knowledge of going to the browser such as using Google helped the learners to query and browse on the Internet. Pan and Jenny were much more independent in their exploration process on the computer as compared to Bruce, who needed a facilitator to be with him most of the time.

Computers were used in the process of artefact building such as building food chains, making mind maps and making books. The use of computers in the process of artefact building was effective when the facilitators told learners what was expected from them to find on the internet and yet provided them the freedom to browse interesting images, videos and webpages and when learners were helped to browse the internet or spell words and/or explained sentences written in English by the facilitators.

\section{Discussion}

In this study the participants, built their understandings about areas of their interest, using a computer as a learning tool. They were given specific tasks by their facilitators related with making artefacts and finding information to make those artefacts. As they engaged in the process of searching information that interested them and was of their choice on the computer, they constructed knowledge. The computers installed in the classroom played an important role in the participants' process of knowledge construction. According to Hayta and Yaprak (2013), Cord-Mounoury (1999 cited in Kartal, 2005) categorized functions of the Internet such as searching for topics on the internet promoted and 
encouraged communication, collaborative and independent learning and provided a great source of information for both learners and facilitators.

The different aspects of computer that helped participants to build their knowledge have been discussed below.

1. Encouraging learner autonomy

Autonomy involves freedom to learn through having choices at various stages of learning and learners having control of their own learning. According to Lee (1998) learner choice is important in autonomous learning and providing choice to learners in their learning helps "to give students a sense of 'ownership' of their learning and thereby add to their intrinsic motivation" (Brown 2001, p. 47 cited in Condrat, 2014). The ability to access information of their own choice easily on their own or with some help from a facilitator and peers' computers may have made participants feel more in control of their knowledge construction, as they had a chance to choose what they wanted to research within their chosen topic. These ideas of participants were not judged by the facilitators. As a result participants felt encouraged and autonomous as they had a say in their learning and more control in it.

Technology has a potential to provide control to learners in their learning and provide them with a sense of responsibility for their learning and encourage self-motivation (Ushioda, 1996 cited in Darasawang \& Reinders, 2010). In this study, participants did not have to only depend on their facilitators or peers for information, instead they had found computers as an alternate source to find information according to their likes Computers helped the participants of this study by providing itself as a resource for inquiry and information and a tool for exploration of ideas. In all the three cases discussed earlier, computers were used to find information about participants' areas of interest. In this study, computers engaged participants with an interface and the potentiality of its being used in multiple ways in the same manner as Papert (1998 cited in Haugland, 2000, p.2) mentioned the use of computers and their impact on children through concrete experiences which are more personal to them (Ackermann, 2001). This in turn may have helped the learners to feel autonomous.

2. Creating meaningful interactions between peers and facilitators

Learners have the need for meaningful classroom experiences; they prefer engaging in solving real world problems and working together and learning from each other (Dunleavy, Milton and Crawford 2010 cited in Taylor and Parsons, 2011). The participants in this study tried to communicate with their foreign facilitators when they found something interesting on the Internet and/or if they had a query or needed any help to find information that interested them. Participants also shared information with their peers during group activities. While sharing information with their peers the participants may have internalized and externalized ideas, combined each other's contributions and built their understandings. Sharing of information in a group is considered significant in knowledge building (Scardamalia, 2002). Researchers (Genishi, 1988; Genishi, McCollum, \& Strand, 1985; Hungate \& Heller, 1984 cited in Clements \& Nastasi, 1992) found that in a computer environment, even if children worked alone, they talked to their peers and consulted with them. Also, children engaged in teaching and helping each other in an environment with computers (Paris \& Morris, 1985; Wright \& Samaras, 1986 cited in Clements \& Nastasi, 1992). Additionally, in Papert's constructionism, social interactions are significant in the process of learning or cognitive development (Ackermann, 2001).

\section{IMPLICATIONS}

This study aims to provide a better understanding of the role of computers in a constructionist learning environment of a young learner classroom. It especially indicates the importance of computers in encouraging exploration, learner autonomy and generating meaningful interactions during the knowledge construction process. Learners using internet can expand and find more information in their domain of interest and sometimes even develop their interest in other domains by reaching a new area while browsing the Internet. Papert and Caperton (1999) also described the holistic and transformative characteristic of computers in knowledge production and distribution. Providing learners a choice at different stages of learning and an easy access to computers can make them feel autonomous and help them to have more control on their learning. Learners have also been found to prefer autonomy in their own learning (Carlson, 2005; Hay, 2000; Glenn, 2000 \& Tapscott, 1998 cited in Taylor \& Parsons, 2011). Computers may also provide opportunities to learners to share their new findings with their peers. These would be findings of learners' choice and of their interest and therefore personal to them. Their interactions with their peers would thus be more meaningful.

Educators who are involved in the area of young learners' education should provide learners with concrete experiences while using computers as a learning mediation tool. This could be done only when they are provided choice in their learning such that learning is more personal to them and they can relate to it.

Artefact building activities should be designed in such a way that young learners relate with those activities and are motivated to work on them. They should be provided with clear direction from the facilitators for the activities with examples, however they must get enough chance to choose and decide their topics of interest. The help provided by the facilitators must be such that learners do not feel limited or guided too much and have the space for themselves to make errors and explore.

\section{CONCLUSON}

In this study, it was observed how using computers as a learning mediation tool helped in the knowledge construction 
of young learners. Computers not only provided learners specific information about areas of their interest but also stimulated learners to browse and find more information. Young learners, when provided with computers, had a sense of control in their learning process. They built their understandings by meaningfully interacting with their peers and facilitators as they had something to show and share with them on the computer. Facilitators' support helped learners to effectively use computers in their knowledge construction as they received freedom to practice their choice, enough space to explore on their own and help with their reading and writing words as and when they needed.

\section{REFERENCES}

[1] Ackermann, E. (2001). 'Piaget's Constructivism, Papert's Constructionism: What's the difference?' Retrieved from: https://pdfs.semanticscholar.org/89cb/cc1e740a4591443ff4765a6ae8df0fdf5554.pdf?_ga=2.83832086.1202394924.155349452 3-1327374052.1553494523 (accessed 21/7/2017) .

[2] Beynon, M. (2017). 'Mindstorms Revisited: Making New Construals of Seymour Papert's Legacy'. Advances in Intelligent Systems and Computing, Vol. 560, 3-19. doi:10.1007/978-3-319-55553-9_1

[3] Binder, S.L. \& Ledger, B. (1985) 'Preschool Computer Project Report'. Oakville, Ontario: Sheridan College.

[4] Brown, D. H. (2001). Teaching by Principles. An Interactive Approach to Language Pedagogy. Second Edition. Longman, Lebanon, Indiana, U.S.A.

[5] Carlson, S. (2005). 'The Net Generation goes to college'. The Chronicle of Higher Education, Section: Information Technology, Vol. 52 No. 7, Retrieved on October 30, 2010 from: https://www.chronicle.com/article/The-Net-Generation-Goes-to/12307.

[6] Clements, D.H. \& Nastasi, B.K. (1992). 'Computers and Early Childhood Education', in Gettinger, M., Elliott, S.N. \& Kratochwill, T.R. (Eds) Advances in School Psychology: Preschool and early childhood treatment directions, pp. 187-246. Hillsdale: Lawrence Erlbaum Associates.

[7] Clements, D.H. and Sarama, J. (2003). 'Strip mining for gold: Research and policy in educational technology - a response to "Fool's gold"', AACE Journal, Vol. 11 No. 1, pp. 7-69.

[8] Condrat, V. (2014). 'The Use of Technology to Promote Learner Autonomy', in Creativitatea lingvala: de la semn la text, Iaşi, Editura PIM.

[9] Cord-Mounoury, B. (1999). 'Analyse du site Lire-français', ALSIC, Vol. 2 No. 4, pp. 49-61. Retrieved from: http://alsic.ustrasbg.fr/Num4/cord/defaut.htm (accessed 4/5/2019).

[10] Darasawang, P., \& Reinders, H. (2010). ‘Encouraging Autonomy with an Online Language Support System', CALL-EJ Online, 11(2).

[11] Dunleavy, J., Milton, P. \& Crawford, C. (2010). 'The Search for Competence in the 21st Century'. Quest Journal 2010. Leading Edge Learning.ca (Abstract) p. 20 Retrieved 2010 October from http://www.leadingedgelearning.ca/q2010/Docs/QuestJournal2010/Article12.pdf.

[12] Edwards, S. (2005) 'Children's learning and developmental potential: Examining the theoretical informants of early childhood curricula from the educator's perspective'. Early Years, Vol. 25 No. 1, pp. 67-80.

[13] Edwards, S. (2005). 'Constructivism does not only happen in the individual: Sociocultural theory and early childhood education'. Early Child Development and Care, Vol. 175 No.1, pp. 37-47.

[14] Falbel, A. (1990). 'The computer as a convivial tool'. In I. Harel (Ed.). Constructionist learning: A 5th anniversary collection of papers. Cambridge, MA: MIT Media Laboratory. Retrieved on May 102019 from http://www.iditharel.com/wpcontent/uploads/2014/09/Harel-Papert-Paper.pdf

[15] Falbel, A. (1993). 'Constructionism: Tools to Build (and Think) with', Toronto: LEGO DACTA and Massachusetts Institute of Technology. Retrieved from: http://learning.media.mit.edu/courses/mas713/readings/Constructionism\%20-\%20Falbel.pdf (accessed 12/4/2019).

[16] Fosnot, C. T. (2005). Constructivism: Theory, perspectives, and practice. New York: Teachers College Press.

[17] Genishi, C. (1988). 'Kindergartners and computers: A case study of six children'. The Elementary School Journal, Vol. 89, pp. 184-201.

[18] Genishi, C., McCollum, P., \& Strand, E. B. (1985). 'Research currents: The interactional richness of children's computer use'. Language Arts, Vol. 62 No. 5, pp. 526-532.

[19] Glenn, J. M. (2000). 'Teaching the Net Generation'. Business Education Forum Vol. 54 No. 3, pp. 6-14.

[20] Griffin, J. M. (2018). 'Constructionism \& De-Constructionism as Complementary Pedagogies'. In Dagiene V. \& Jasute E. (Eds.) Constructionism 2018. Conference proceedings of Constructionsim 2018, Vilnius University, Vilnius, Lithuania, pp. 225 - 237, Retrieved from: https://www.researchgate.net/publication/327192613_Constructionism_and_DeConstructionism_as_Complementary_Pedagogies (accessed 13/4/2019).

[21] Han, S. \& Bhattacharya, K. (2001). 'Constructionism, Learning by Design, and Project-based Learning'. In M. Orey (ed), Emerging perspectives on learning, teaching, and technology. Retrieved from: http://www.coe.uga.edu/epltt/LearningbyDesign.htm (accessed 22/12/2018).

[22] Harel, I., \& Papert, S., (1990). 'Software design as a learning environment'. Interactive Learning Environments, Vol. 1, No. 1, pp. 1-32.

[23] Haugland, S.W. (2000). 'What Role Should Technology Play in Young Children's Learning? Part 2. Early Childhood Classrooms in the 21st Century: Using Computers to Maximize Learning'. Young Children. Vol. 55 No. 1, pp. 12-18.

[24] Hay, L. E. (2000). 'Educating the Net Generation'. The Social Administrator Vol. 57 No. 54, pp. 6-10.

[25] Hayta, F., \& Yaprak, Z. (2013). Learner Autonomy and Computer Technology as a Facilitator of Autonomous Language Learning, Journal of Education and Instructional Studies in the World, Vol. 3 No. 2, pp. 57 - 63.

[26] Hoven, D. (2006). 'Communicating and interacting: An exploration of the changing roles of media in CALL/CMC'. CALICO Journal, Vol. 23, pp. 233-256.

[27] Hungate, H., \& Heller, J. I. (1984). 'Preschool children and microcomputers'. Paper presented at the meeting of the American Educational Research Association, New Orleans. 
[28] Kartal, E. (2005). 'The Internet and Autonomous Language Learning: A Typology of Suggested Aids', Turkish Online Journal of Educational Technology - TOJET, Vol. 4 No. 4, pp. 54-58

[29] Kimmerle, J., Moskaliuk, J., Oeberst, A. \& Cress, U. (2015). 'Learning and Collective Knowledge Construction with Social Media: A Process-Oriented Perspective', Educational Psychologist, Vol. 50 No. 2, pp. 120-137.

[30] Klinzing, D. G., \& Hall A. (1985). 'A study of the behavior of children in a preschool equipped with computers'. American Educational Research Association, Chicago.

[31] Lamb, A. \& Johnson, L. (2011). 'Scratch: Computer Programming for 21st Century Learners'. Teacher Librarian. Vol. 38 No. 4, pp. 64 - 75. ProQuest Central, Retrieved from: https://scholarworks.iupui.edu/bitstream/handle/1805/8622/384.pdf? sequence $=1$ (accessed 12/4/2019).

[32] Lee, I. (1998). 'Supporting Greater Autonomy in Language Learning', ELT Journal Vol. 52 No. 4, Oxford University Press, Oxford, U.K

[33] Lee, L. (2015). 'Digital Media and Young Children's Learning: A Case Study of Using iPads in American Preschools', International Journal of Information and Education Technology, Vol. 5 No. 12, pp. 947-950, doi: 10.7763/IJIET.2015.V5.643

[34] McCarrick, K. and Li, X. (2007). 'Buried treasure: The impact of computer use on children's social, cognitive, language development and motivation', AACE Journal, Vol. 15 No. 1, pp. 73-95.

[35] Mills, J. (2007). 'Constructivism in Early Childhood Education'. Perspectives In Learning, Vol. 8 No. 2. Retrieved from: http://csuepress.columbusstate.edu/pil/vol8/iss2/8 (accessed 21/11/2018).

[36] O'Bryan, A. (2008). 'Providing pedagogical leaner training in CALL: Impact on student use of language learning strategies and glosses'. CALICO Journal, Vol. 26 No.1, pp. 142-159.

[37] Palmer, D. (2005). 'A motivational view of constructivist-informed teaching'. International Journal of Science Education, Vol. 27 No.15, pp. 1853-1881.

[38] Papert, S. (1980). Mindstorms - Children, Computers and Powerful Ideas. New York: Basic Books.

[39] Papert, S. (1987). 'Constructionism: A New Opportunity for Elementary Science Education', NSF Award Abstract (\#8751190). Retrieved on March 262019 from: https://nsf.gov/awardsearch/showAward?AWD_ID=8751190

[40] Papert, S. (1996). The Connected Family. Atlanta, Georgia: Longstreet Press.

[41] Papert, S. (1998). 'Technology in schools: To support the system or render it obsolete'. Milken Exchange on Education Technology, retrieved on January 25, 2000 from: http://www. mff.org/edtech/article.taf?_function=detail\&Content_uid1=106.

[42] Papert, S., Caperton, G. (1999). 'Vision for Education: The Caperton-Papert Platform', An Essay written for The 91st annual National Governors' Association Meeting, St. Louis, Missouri, Retrieved from: http://www.papert.org/articles/Vision_for_education.html (accessed 10/04/2019).

[43] Papert, S, \& Harel, I. (1991). 'Situating Constructionism'. In I. Harel, \& S. Papert, Constructionism, pp. 32-64, Norwood, NJ: Ablex Publishing. Retrieved from: http://www.papert.org/articles/SituatingConstructionism.html (accessed 15/10/2018).

[44] Paris, C. L., \& Morris, S. K. (1985). 'The computer in the early childhood classroom: Peer helping and peer teaching' - a paper presented at the meeting of the Microworld for Young Children Conference, Cleege Park, MD.

[45] Scardamalia, M. (2002). 'Collective cognitive responsibility for the advancement of knowledge'. In B. Smith (Ed.), Liberal education in a knowledge society, pp. 67-98, Chicago, IL: Open Court.

[46] Spink, Amanda H. and Danby, Susan J. and Mallan, Kerry M. and Butler, Carly. (2010). 'Exploring young children's web searching and technoliteracy'. Journal of Documentation, Vol. 66 No. 2. pp. 191-206.

[47] Sripongwiwat, S., Bunterm, T., Srisawat, N., \& Tang K. N. (2016). 'The constructionism and neurocognitive-based teaching model for promoting science learning outcomes and creative thinking', Asia-Pacific Forum on Science Learning and Teaching, Vol. 17 No. 2, Retrieved from: https://www.eduhk.hk/apfslt/v17_issue2/tassanee/index.htm\#con (accessed 23/10/2018).

[48] Stager, G. (2005). 'Papertian Constructionism and the Design of Productive Contexts for Learning'. Eurologo, pp. $43-53$. Warsaw.

[49] Tapscott, D. (1998). Growing up digital: the rise of the Net generation. New York: McGrawHill.

[50] Taylor, L. \& Parsons, J. (2011). 'Improving Student Engagement'. Current Issues in Education, Vol. 14 No. 1. Retrieved on May 52019 from https://cie.asu.edu/ojs/index.php/cieatasu/article/view/745/162.

[51] Turkle, S. \& Papert S. (1990). 'Epistemological Pluralism: Styles and Voices within the Computer Culture', Constructionist Learning - A 5th Anniversary Collection of Papers Reflecting: Research Reports, Projects in Progress and Essays by the Epistemology \& Learning Group, presented at the Epistemology \& Learning Group during the Annual meeting of the American Educational Research Association (AERA) pp. 345 - 378.

[52] Ushioda, E. (1996). 'Learner autonomy 5: The role of motivation'. Dublin: Authentik.

[53] Vygotsky, L. S. (1978). Mind in Society. (M. Cole, V. John-Steiner, S. Scribner, \& E. Souberman, Eds.) Cambridge, MA, USA: Harvard University Press.

[54] Windschitl, M. (2002). 'Framing constructivism in practice as the negotiation of dilemmas: An analysis of the conceptual, pedagogical, cultural, and political challenges facing teachers'. Review of Educational Research, Vol. 72 No.2, pp. 131-175.

[55] Winke, P., \& Goertler, S. (2008). 'Did we forget someone? Students' computer access and literacy for CALL'. CALICO Journal, Vol. 25, pp. 482-509.

[56] Wright, J. L., \& Samaras, A. S. (1986). 'Play worlds and microworlds'. In Campbell, P. F. \& Fein, G. G. (Eds.), Young children and microcomputers, pp. 73-86. Reston, VA: Reston Publishing.

Archana Joshi is a facilitator at Darunsikkhalai School for Innovative Learning, King Mongkut's University of Technology Thonburi (KMUTT). She obtained her Master Degree in Ancient Indian History from Chaudhary Charan Singh University, Meerut (India). She is a Ph.D. candidate in Applied Linguistics, School of Liberal Arts, King Mongkut's University of Technology Thonburi (Thailand). 
Pornapit Darasawang is Vice President for Internationalisation, King Mongkut's University of Technology Thonburi (KMUTT). She obtained her B.A. in English from Chulalongkorn University, Thailand; M.Ed. in Reading from Towson State University, USA; M.A in TESOL from the Moray House Institute of Education, Heriott-Watt University, UK and Ph.D in TESOL from the University of Edinburgh. She is also a Director of Studies of the PhD in Applied Linguistics.

Saowaluck Tepsuriwong is Head of the Department of Language Studies, King Mongkut's University of Technology Thonburi (KMUTT). She obtained her Ph.D in Applied Linguistics from the University of Reading, UK. She has been teaching courses on language learning, materials design, and teaching pedagogy. 